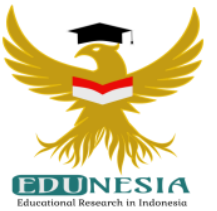

\title{
Ondel-Ondel Local Content Curriculum as A Vocational School of Betawi Cultural Preservation
}

\author{
Aji Cahya Gumelar1; Fatihah Ekawati2; \\ Fitriani Intan Purnamasari ${ }^{3}$; Zharra Cynthia Dewi ${ }^{4}$
}

\author{
1,2,3,4Education Administration, Universitas Muhammadiyah Prof. Dr. Hamka, Indonesia \\ ${ }^{1}$ Corresponding Email: ajicahyagumelar@gmail.com, Phone Number: 0813 xxxx xxxx
}

\author{
Article History: \\ Received: Feb 11, 2021 \\ Revised: July 03, 2021 \\ Accepted: July 04, 2021 \\ Online First: July 07, 2021
}

\section{Keywords:}

Betawi Culture, Ondel-ondel, local content curriculum.

\section{Kata Kunci:}

Budaya Betawi, Ondel-ondel, Kurikulum Muatan Lokal.

\section{How to cite: \\ Gumelar, A.C., Ekawati, F., Purnamasari, F.I., \& Dewi, Z.C. (2021). Ondel-Ondel Local Content Curriculum as A Vocational School of Betawi Cultural Preservation. Edunesia: Jurnal Ilmiah Pendidikan, 2 (3): 607-618}

This is an open access article under the $C C-B Y-N C-N D$ license

\begin{abstract}
The research objective was to implement the learning process ondel-ondel arts in local content in the form of music, dance, and fine art compositions at the Vocational High School level as an effort to preserve Betawi culture. This research was conducted using a qualitative approach with interview techniques, observation, literature study, and triangulation techniques. Music composition for ondel-ondel art only relies on the trumpet as an instrument that plays a melody or song. The song that was played was limited to only 2 songs, namely Leles and Mangle. Ondel-ondel art in terms of visual art, students are able to make ondel-ondel masks using recycled materials, besides that in terms of the ondel-ondel art dance uses free movements that can be pulled by students at a show using several musical instruments that are still maintained until now. The implementation of local content in schools provides provisions for knowledge, skills, behavioral orders and student behavior, in the form of insight into environmental conditions and local wisdom.
\end{abstract}

Abstrak: Tujuan penelitian_untuk mengimplementasikan proses pembelajaran kesenian ondel-ondel dalam kurikulum muatan lokal dalam bentuk komposisi iringan musik, tarian, dan seni rupa pada jenjang Sekolah Menengah Kejuruan (SMK) sebagai upaya pelestarian budaya Betawi. Penelitian ini dilakukan menggunakan pendekatan kualitatif dengan teknik pengumpulan data melalui wawancara, observasi, studi literatur, dan teknik triangulasi. Komposisi musik untuk kesenian ondel-ondel hanya mengandalkan terompet sebagai instrumen yang memainkan melodi atau lagu. Lagu yang dimainkan pun terbatas hanya 2 buah lagu saja yaitu Leles dan Mangle. Kesenian ondel-ondel ditinjau dari seni rupa siswa mampu membuat topeng ondel-ondel menggunakan bahan daur ulang, selain itu ditinjau dari seni tari kesenian ondelondel menggunakan gerakan bebas yang dapat di tarikan oleh siswa pada sebuah pertunjukan menggunakan beberapa alat musik yang masih tetap dipertahankan sampai sekarang. Implementasi kurikulum muatan lokal di sekolah memberikan bekal pengetahuan, keterampilan, pembentukan sikap dan perilaku siswa, berupa wawasan tentang keadaan lingkungan dan kearifan lokal. 


\section{A. Introduction}

Local content curriculum taught in schools is a way to develop student competencies according to the potential and characteristics of the region. Students are more familiar with the social environment and regional culture, and motivated to preserve the culture and environment. Local content curriculum is very much needed as an effort to preserve culture by the younger generation within the scope of education (Zainal, 2011). Regional Regulation Number 4 of 2015 issued by the DKI Jakarta Government contains the Preservation of Betawi Culture, as an effort to preserve local culture. One of them is by including Betawi Culture in educational institutions through local content curriculum. The learning environment model through learning objects of diverse local cultures can strengthen the character of the nation (Arifin et al., 2018). The orientation of the local content curriculum linked to national education goals with the needs of the community. An area can determine subjects that contain characteristics of local culture, noble values, social problems, and basic skills for students as provisions in their lives.

The development of local content is an educational curriculum whose delivery is related to natural, social, cultural, and regional potential conditions (Wasliman, 2007). Local content curriculum material aims to develop competencies that are in accordance with local wisdom. Local content cant be grouped into existing subjects so that it is used as a curricular activity (Mulyasa, 2009). The scope of local content includes: (1) the scope of local conditions and needs. (2) the scope of content or types of local content, may be in the form of: language, regional arts, regional skills and crafts, customs, and knowledge of various characteristics of the surrounding natural environment, as well as other matters deemed necessary by the region concerned.

The principle of curriculum development regulated in Permendikbud number 79 of 2014 is centered on the development, potential, interests, and needs of students, appropriate and integrated with a diverse environment. In order to students are responsive to the development of science, art, and technology that are relevant to the needs of a sustainable and balanced life. Local content can be combined with all subjects other than subjects in the national content, as an extracurricular, or as a separate subject. Local content determined by the school provides skills to students and forms attitudes that reflect the traditions of the region.

The criteria for selecting local content learning materials are: (a) in accordance with the development of students. (b) do not deviate from the elements of Pancasila. (c) does not conflict with the preservation of anything in the area such as natural, social, cultural and others. (d) useful for students and their area. (e) take into account the time required to deliver it and implement it (Zainal, 2011). Local content prepares students to have the insight, skills, attitudes, and values of local wisdom. Students can also participate in the conservation and development of natural resources, and improve the socio-cultural quality of their area in accordance with the direction of regional development.

Indonesia has 1,340 ethnic groups. Each ethnic group has a unique culture in each region. The Betawi tribe is a term for indigenous people in the city of Jakarta, this tribe was formed from mixed marriages between ethnicities and foreign nations during the colonial period. With the marriage, there are several new arts and cultures that are characteristic of the Betawi tribe, one of which is ondel-ondel. Ondel-ondel is a large paired doll, made of woven bamboo, which wears a mask and has palm fiber hair. The red mask is depicted as ondel-ondel Abang, the white mask represents ondel-ondel None. 
Ondel-ondel is an art that developed in the Jakarta area. The history of this art begins with the story of a village affected by a skin disease outbreak, the villagers make a large doll symbol that aims to ward off evil and ward off evil spirits. Large dolls are paraded around the village and a special ritual is performed. The doll is known as ondel-ondel (Kustopo, 2008).

In this era of globalization, the younger generation is not too interested in studying regional arts and culture which has many noble values, they prefer to study culture from abroad. This is one proof that young people's appreciation of local culture is very lacking. This is where action is needed to preserve local culture (Arifin et al., 2018). Culture maintenance is carried out continuously and gradually to achieve something that is eternal, selective, and adaptive (Jacobus, 2006).

The local content curriculum at every level of education has its own uniqueness and characteristics which are cultural values and local wisdom that are maintained along with the changing times. The local content curriculum is structured according to the regional potential and the development of students, as well as the competencies expected to face global challenges (Hafinda, 2020). Local content in Pergub DKI Jakarta Province Number 86 of 2018 is developed in the form of separate and/or integrated subjects including: a. Betawi Culture and Jakarta Culture. b. Science and Technology. c. Jakarta Environment. d. Foreign languages that developed in Jakarta.

In the era of globalization, foreign cultures can easily threaten the original culture of Indonesia. Indonesian culture is lost or claimed by other countries. Preservation of Indonesian culture can be done by introducing it to the younger generation from an early age, so that a sense of love and desire to preserve Indonesian culture grows. However, there is no curriculum that specifically explains Indonesian culture. At first glance, Indonesian culture is only studied in Social Science subjects (Dwisaputra et al, 2012).

In an effort to preserve Indonesian culture, especially ondel-ondel, learning materials about ondel-ondel art are included in the local content curriculum in schools. Ondel-ondel art materials can be applied to local content subjects in vocational high schools. Students gain a thorough knowledge and understanding of ondel-ondel art through these learning materials. Students can connect the learning process carried out at school with community life and culture in their environment.

Research on ondel-ondel culture has been conducted by Susanto, in this study, explained that ondel-ondel performances have undergone changes in the use of musical instruments and performances (Susanto, 2019). The local content curriculum aims to develop regional potential through education and maintain and preserve Indonesian culture (Arifin et al., 2018). Nasir in his research concludes that values, traditions, culture, skills and concepts that apply to society can be preserved through educational activities. The local content curriculum aims to make students have academic knowledge, and understand the traditions of their community (Nasir, 2013).

\section{B. Method}

This study uses a qualitative approach so as to provide an overview of the conditions or circumstances under study. This approach provides an understanding of the substance of an event and can provide a more in-depth description/explanation (Sofaer, 1999). This is in accordance with the purpose of this study, which is to provide an overview of ondelondel art and its application and development in local content curriculum in Vocational School. 
The research locations for classical ondel-ondel performances were carried out at the Ondel-Ondel Beringin Sakti Studio, East Jakarta, and the Betawi Light Studio in Rawasari, Central Jakarta. Information about the ondel-ondel performance was obtained from an interview with Mr. Juwahir, the chief of the Cahaya Betawi studio, located in Rawasari, Central Jakarta. Interviews were also conducted with Mr. Yasin, the chief of Sanggar Beringin Sakti, which is located on fir street, East Jakarta. Information about the application of ondel-ondel in the local content curriculum was obtained from interviews with teachers at SMKN 57 Jakarta. To compare the validity of the information, the researcher also interviewed Mr. H. Yoyo Muchtar, as the chief of the Division of Preservation and Empowerment at the Betawi Cultural Institute.

Data was collected by triangulation technique which is defined as a data collection technique that combines various data collection techniques from existing data sources (Sugiyono, 2017). Research based on direct field observations. The qualitative approach provides data in the form of spoken and written words from the research subject. Data collection was done through observation techniques, literature studies, interviews with studio owners, ondel-ondel music players, Jakarta cultural experts and teachers teaching local content at SMKN 57 Jakarta. Data were analyzed using the Miles and Huberman model, namely data reduction activities, data display, and verification (Sugiyono, 2017). Testing the validity of the research data (primary and secondary) was carried out using the credibility criteria followed by examination techniques (Moelong, 2007).

\section{Result and Discussion}

Ondel-ondel as Betawi culture has existed since the 15th century. Previously it was called barongan which means together. Benyamin Sueb as one of the Betawi artists introduced the song ondel-ondel, since then the barongan is better known as ondel-ondel. In the 15th century ondel-ondel acted as ancestral spirits who guarded the villagers. At that time, people still believed in mystical things, so they made ondel-ondel as an intermediary for ancestral spirits. The shape and size at that time had a sinister face, curled, and long hair, and had a larger size than today's ondel-ondel. Ondel-ondel has parts consisting of:

1) Head, there is a crown decorated with paintings such as a peacock/hong, dragon, lotus flower, pomegranate flower, and clover. Above the head of the ondel-ondel there is also a coconut flower shaped like a collection of coconut leaves as a symbol of the Sunda Kelapa region.

2) The face of the red male ondel-ondel doll symbolizes strength, power, courage, and a hard ego. The face of the white female ondel-ondel doll symbolizes purity, tenderness, friendliness, and majesty.

3) Men's ondel-ondel doll clothes use a sadariah or ujung serong. At the bottom use a holster jamblang. On certain occasions, a cunin sarong with a square pattern is draped over the shoulder. The female doll is wearing a kebaya encim. In certain events, use a scarf with floral and animal motifs.

Musical instruments in ondel-ondel art use 3 gongs consisting of kempul, kemor, kenong, 2 drums consisting of a big drum and small bolster drum, 1 kecrek, and 1 trumpet. Along with its development, kecrek and trumpet are no longer used, replaced with tambourines and tehyan. The trumpet which is the hallmark of ondel-ondel music is replaced with the tehyan musical instrument, because of the difficulty of playing it (Susanto, 2019). These musical instruments have different playing patterns and functions, the big drum serves to set the initial tempo to enter the drum, and as a fill in for the song to be 
played, the small drum is a complement to the big drum as a fill in or code in certain parts, tahyan plays the melody in the catfish and mangle sections. The use of trumpets in the composition of ondel-ondel art music can only perform 2 songs, namely leles and mangle. Trumpets can only make certain notes. The use of this instrument is considered less effective so it is replaced with kongahyan.

\section{Ondel-Ondel Performance Show}

Sanggar Beringin Sakti is the oldest ondel-ondel studio in Jakarta, until now it is still active and registered with the Jakarta Cultural Institute. Since its establishment, it has always held ondel-ondel performances according to the original, using trumpet instruments and only playing two songs, namely leles and mangle. Sanggar Beringin Sakti replaced the trumpet with tehyan in 1997 . This change was due to:

1) The technique of blowing the trumpet instrument is more difficult than other instruments.

2) Instrument players have difficulty reading musical notes.

3) There is no teacher who teaches the instrument.

The technique of playing the tehyan instrument is relatively easier and more in demand. Tehyan instruments can also play more variations of songs, from traditional Betawi songs to contemporary songs. The music at the Sanggar Beringin Sakti ondel-ondel show has the following order:

\section{Intro}

Music players play the intro slowly to fast with a tempo of 150, entering the leles section. Then the ondel-ondel enter the middle of the performance arena and move freely until the tempo of the music slows down which becomes a sign or fill in entering the mangle section, then the ondel-ondel begins to leave the performance arena.

\section{Opening of Pencak Silat}

In the mangle section, the first fighter enters the middle of the arena. Silat players begin to salute / soja then play moves without weapons. After the fighter has finished playing all the moves, the musicians play the leles song by increasing the tempo of the music or the drum rising. At the end of the performance, the fighter saluted as a closing greeting, then left the performance arena.

\section{Ondel-ondel Free Movement}

After the fighter leaves the performance arena, the ondel-ondel enters and moves freely until the musical accompaniment changes to mangle as a code or fills in. Ondel-ondel leaves the center of the performance arena and is replaced by a silat player.

\section{Silat Duet}

The second silat performance was performed by two people. It starts with saluting / soja, followed by a silat action in a duet. This silat show depicts two people fighting using Toya and Teco weapons. This performance continues until the musical accompaniment 
plays the leles song, and the pesilat salutes / soja as a closing and then leaves the middle of the arena.

\section{Ondel-ondel Free Movement}

After the fighter leaves the performance arena, the ondel-ondel enters and begins to move freely until the musicians switch to playing the mangle song as the code for the ondelondel to leave the center of the performance arena, replaced by a silat player.

\section{Cover Pencak Silat Single and Ondel-ondel}

This last pencak silat performance was played singly. Pesilat pays respects/soja then displays 4-step silat fighters. Then the musicians play the accompaniment of the leles song which is the code for the fighter to salute/soja as a closing, then the fighter leaves the performance arena. At the same time, enter the ondel-ondel in the middle of the arena until the show is over.

\section{Musical Accompaniment Free Motion Ondel-ondel Performance}

Musical accompaniment is the most important part in every ondel-ondel performance. Musical accompaniment aims to describe the situation and part of the ondelondel performance. Ondel-ondel performances have a movement, which is done with free movement following the flow and tempo of the song. In this movement free musical accompaniment, the form of which does not have a standard flow of the song. Generally, the song is taken from several songs in the Gambang Kromong art. In the absence of standard songs that are sung, it is easier for the musical accompaniment of the free movement of ondel-ondel to be included in school learning. In addition, there are several additional musical instruments that can be used in the context of learning at school.

Along with the passage of time and the development of the times, ondel-ondel is currently used in festival events, such as processions on Jakarta's birthday, circumcision or cap-go-meh celebrations and learning at schools. In ancient times musical instruments were played while walking. At this time the show can be performed on stage, arena performances and accompanied by xylophone kromong.

Gambang kromong is a Betawi musical art which is a combination of Chinese and Betawi ethnicities, consisting of two instruments, namely the xylophone and the kromong. The functions of the gambang kromong musical instrument are: 1) accompanying Betawi songs, 2) accompanying Betawi lenong, 3) accompanying Betawi dances, and 4) ondel-ondel free movement music procession. Musical accompaniment in the ondel-ondel show is played quietly in place. The leles song is used to accompany the free-moving ondel-ondel, the mangle song is used to accompany the pencak silat performances. The accompaniment of music at this time uses tehyan and street musicians move around around the ondel-ondel moving freely. Ondel-ondel shows as a whole can only be played by professional players due to the difficulty of learning the accompaniment pattern of ondel-ondel performing arts.

\section{Ondel-ondel Local Content Curriculum at Vocational School}

Based on the results of interviews conducted with productive teachers of Betawi Karawitan Arts at SMKN 57 Jakarta, according to sources, the local content curriculum is 
very important and very useful. Because education does not only study general fields, but also applies learning in the arts and culture of the local area.

Local content subjects are held with the aim that students can understand the local content of local traditions, such as the Jakarta area, we are familiar with the Betawi tribe (Participant, interview, January 2021).

Ondel-ondel performances are usually only studied in Betawi art studios, but at SMKN 57 this ondel-ondel performance has been successfully implemented in the local content curriculum as stated in the interview results as follows:

The mulok material at SMKN 57 studies ondel-ondel music performances. It is considered very effective, because students are required to be able to learn all the arts in Betawi. Mulok learning is very effective to be taught at the SMK level, not only at SMKN 57. Because the tools used in learning ondel-ondel music use musical instruments that are very affordable, every school generally has musical instruments that can support ondel-ondel musical accompaniment learning (Participant, interview, January 2021).

The implementation of the local content curriculum on ondel-ondel material at SMKN 57 begins by providing an understanding of the history of ondel-ondel, performances, and ondel-ondel musical instruments through video displays. As narrated as follows:

We started the lesson by providing an understanding of ondel-ondel's history, the function of ondel-ondel, and musical instruments used to accompany ondel-ondel performance. After that, a video is shown that provides an overview of ondel-ondel music and the stages in the ondel-ondel performance. Students are given an introduction to musical instruments and scores of songs that will be played. In learning the accompaniment of ondel-ondel performances. there is the addition of musical instruments, carried out with the aim of increasing creativity. Students arrange existing songs according to the latest developments and variations to the accompaniment of ondel-ondel performances without losing the originality of the music. (Participant, interview, January 2021).

The ondel-ondel performance which was held in mulok at SMKN 57 experienced a change in the use of musical instruments as conveyed from the results of the interview:

Ondel-ondel musical accompaniment uses several musical instruments. Kongahyan is used to play the main melody instead of the trumpet. The technique of playing the Kongahyan musical instrument is easier than playing the trumpet (Participant, interview, January 2021).

The problem in implementing the curriculum for local ondel-ondel dschools is the lack of resource persons and research on Betawi Culture. this causes a lack of teachers who have competence in the field of Betawi Cultural arts. As stated in the interview results as follows:

The Betawi culture mulok curriculum in schools is more about art in general or what is called the traditional art of the archipelago. This is all due to the lack of research in the Betawi cultural arts field. In addition, the lack of competent teachers in the field of Betawi cultural arts has resulted in the application of the Betawi local content curriculum not being maximized (Participant, interview, January 2021). 


\section{Discussion}

This ondel-ondel free motion performance material can be applied in several subjects in the local content curriculum, including the Jakarta Cultural Environmental Education lessons, Music Arts, Dance Arts, and Fine Arts at the SMK level, with the aim that students can play accompaniment patterns. music, movement patterns, and also making ondel-ondel dolls. Musical accompaniment ondel-ondel free motion that can be done at school is the xylophone kromong instrument. The following is an overview of the technique of playing the xylophone kromong instrument that is suitable for students, including:

\section{a. Kongahyan}

It is a traditional Betawi musical instrument. This musical instrument is found in the xylophone kromong art and is included in the type of melodic musical instrument. Kongahyan is played by swiping on the two strings on the instrument. Along with its development, konghayan is used in ondel-ondel performances to replace the role of trumpets. Because kongahyan has more advantages than the resulting tone. Kongahyan in his appearance can play all melodies and scales unlike the trumpet which does not produce many melodies.

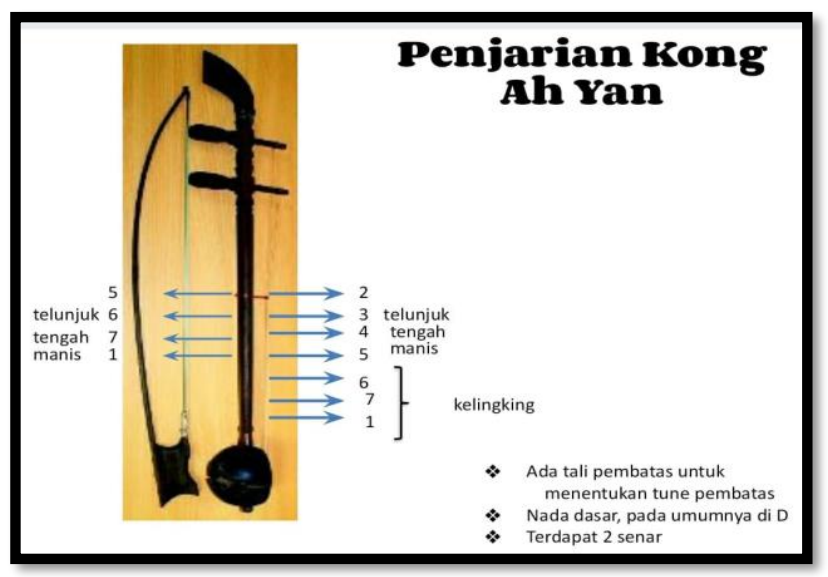

Figure 1. Kongahyan.

\section{b. Xylophone}

This musical instrument is an instrument that exists in the gambang kromong art, in its appearance the wooden xylophone functions as a substitute for the bass. The wooden xylophone is made of teak wood. Has a sequence of notes from low to high pitch.

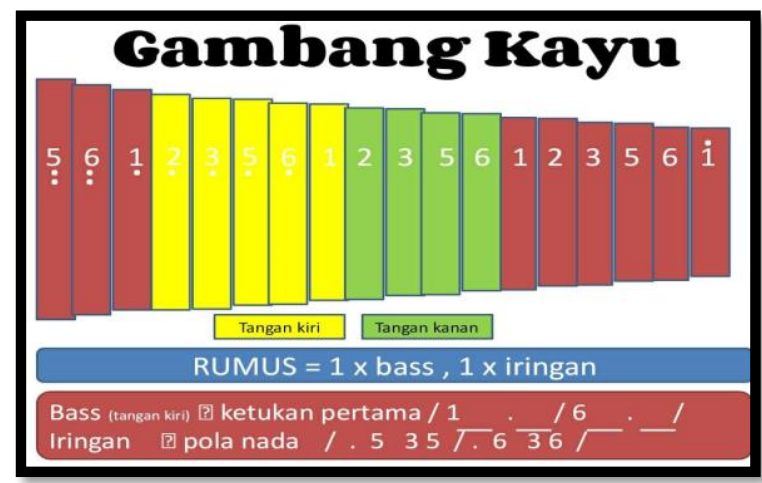

Figure 2. Xylophone 
c. Kromong

Kromong is made of Bronze, in appearance the Kromong functions as an accompaniment carrier. Kromong consists of 10 pencons.

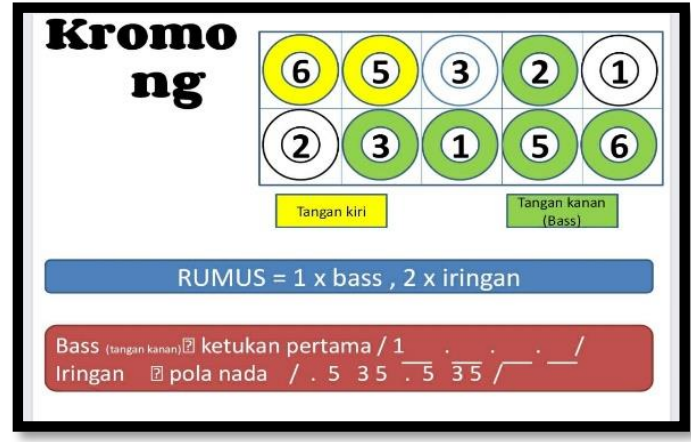

Figure 3. Kromong

d. Drum

The drum is a musical instrument that is not pitched, in its appearance the drum functions as a tempo controller of the song. This musical instrument consists of 1 large drum and 2 small drums.

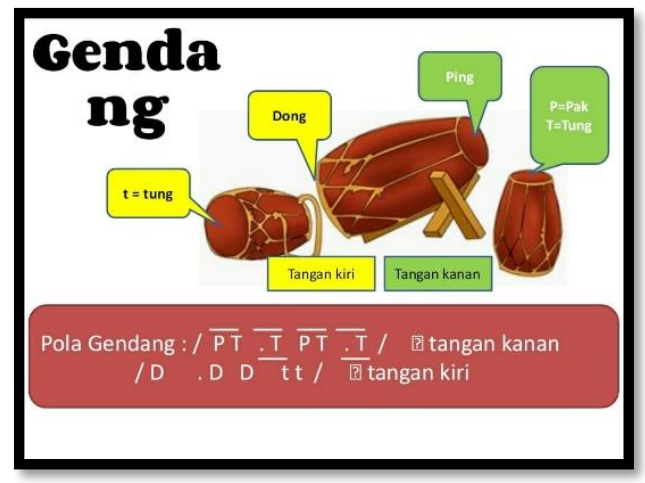

Figure 4. Drum

e. Kecrek

Kecrek is made using iron/bronze. Functions as a song tempo controller.

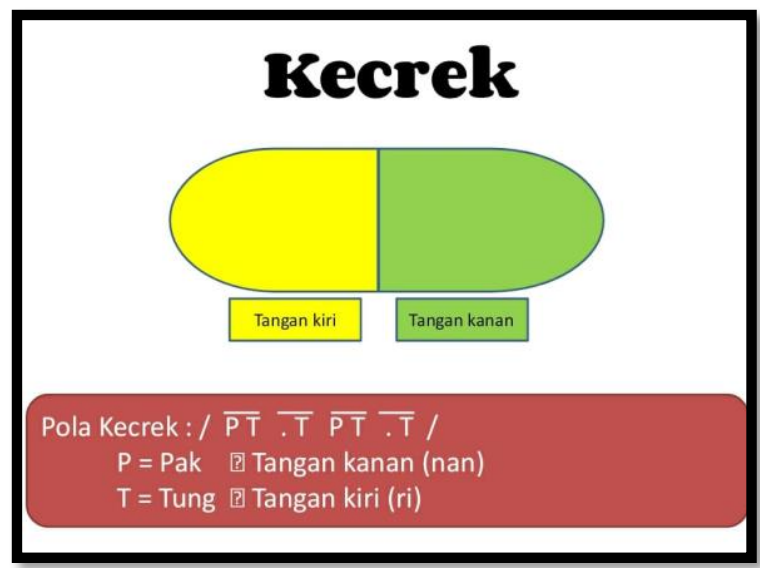

Figure 5. Kecrek 
f. Gong

The gong is made of iron/bronze, consisting of a smaller kempul and a larger gong. Gong is generally played by one person using a bat.

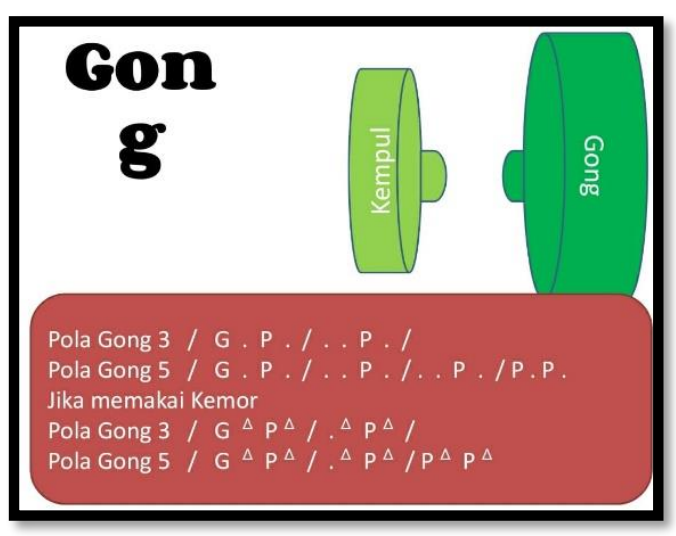

Figure 6. Gong

Below is an overall sheet music accompaniment for the free movement of ondelondel that can be applied in the mulok learning of Jakarta Cultural Environment Education and the art of music. Traditional Betawi uses the musical instrument xylophone kromong.

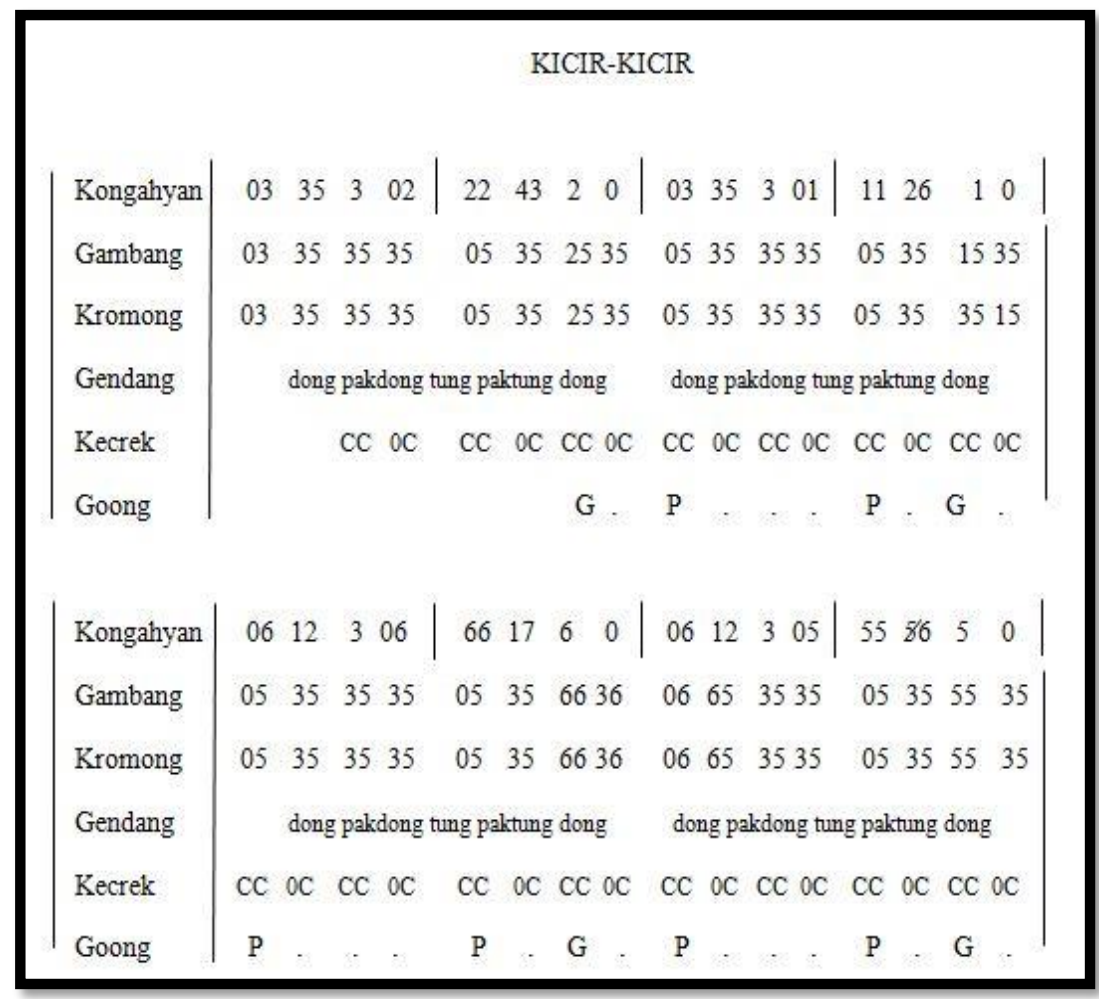

Figure 7. Sheet music accompaniment for free movement of ondel-ondel

Based on the description above, the ondel-ondel local content curriculum can be implemented in schools as an effort to preserve Betawi culture. There needs to be a role for the government, especially the education office, in an effort to prepare competent teaching staff in mulok subjects. So that when the teacher is given the task by the school to hold Mulok 
subjects, he can understand and can provide accurate knowledge and can be understood by students.

\section{Conclusion}

The cultural wealth of Indonesia today is starting to disappear, eroded by the times and influences from outside cultures. To preserve Indonesian culture, it is hoped that the role of the government and the education office will be in an effort to develop and introduce local arts through learning activities in schools. With the study of the local content of Betawi art, it is hoped that it will become a reference in mulok learning at school.

Based on the results of the research above, ondel-ondel performances can be used as local content learning materials to enrich students' cultural treasures in understanding local wisdom. The ondel-ondel show as a whole has several structures and standards in its appearance. Accompaniment of ondel-ondel music, free movement is considered the easiest to learn and apply in the ondel-ondel procession in various situations and conditions. Students are expected to be able to play free-motion musical accompaniment in ondel-ondel art using the musical instruments of tehyan, kohyan, xylophone, kromong, kecrek, drums, and gongs. This musical instrument can be played as an accompaniment to ondel-ondel art with simple musical compositions. In this study there are scores of ondel-ondel performances for free movement and techniques for playing musical instruments written in the form of sheet music using numerical notes. With the musical accompaniment song used entitled Kicir-kicir. The techniques written in this study consist of the musical instrument techniques of tehyan/kongahyan, xylophone, kromong, drum, kecrek, and gong.

In addition to performing music, ondel-ondel is also included in dance lessons which aims to make students understand and dance according to the ondel-ondel movement pattern. Ondel-ondel art can be included in fine arts lessons which aim to make students have knowledge of how to make ondel-ondel masks using recycled paper. In the material for Environmental and Cultural Education in Jakarta, students can understand social and cultural conditions as well as local wisdom.

\section{References}

Arifin, M. Z., Ulfa, S., \& Praherdhiono, H. (2018). Pengembangan kurikulum muatan lokal karawitan sebagai upaya mengkonstruksi pengetahuan dan pelestarian budaya jawa di jenjang sma. Jurnal Kajian Teknologi Pendidikan, 1, 2-10.

Dwisaputra, S., Mutiara, G. A., \& Pudjoatmodjo, B. (2012). Aplikasi Pembelajaran Interaktif Kebudayaan Indonesia Untuk Sekolah Dasar Kelas 1-4.

Hafinda, T. (2020). Evaluasi Pengembangan Kurikulum Muatan Lokal Sekolah Dasar Negeri Kota Meulaboh. At-Ta'dib: Jurnal Ilmiah Prodi Pendidikan Agama Islam, 31. https://doi.org/10.47498/tadib.v12i01.317.

Wasliman, I. (2007). Modul problematika pendidikan dasar. UPI PRESS.

Jacobus, R. (2006). Sistem sosial budaya Indonesia. Ghalia Indonesia.

Kustopo. (2008). Mengenal Kesenian Nasional Ondel-ondel. PT. Bengawan Ilmu. 
Moelong, J. L. (2007). Metodologi penelitian kualitatif. PT. Remaja Rosdakarya.

Mulyasa, E. (2009). Impelementasi kurikulum tingkat satuan pendidikan, kemandirian guru dan kepala sekolah. PT. Bumi Aksara.

Nasir, M. (2013). Pengembangan Kurikulum Muatan Lokal Dalam Konteks Pendidikan Islam Di Madrasah. HUNAFA: Jurnal Studia Islamika, 10(1), 1. https://doi.org/10.24239/jsi.v10i1.12.1-18.

Sofaer, S. (1999). Qualitative methods: what are they and why use them. Health Services Research Part II.

Sugiyono. (2017). Metode penelitian kuntitatif, kualitatif dan RED. Alfabeta.

Susanto, J. (2019). Kajian Kesenian Ondel-ondel di Tinjau Dari Komposisi Musik di Sanggar Beringin Sakti.

Zainal, A. (2011). Konsep dan Model Pengembangan Kurikulum. PT. Remaja Rosdakarya. 